\title{
AKTIVITAS ANTIFOTOOKSIDASI DAN FOTOPROTEKSI FRAKSI PELARUT DARI DAUN GEDI (Abelmuschus manihot L)
}

\author{
Reliana Abigael $^{1 *}$, Edi Suryanto ${ }^{1}$ dan Dewa G. Katja ${ }^{1}$ \\ ${ }^{1}$ Jurusan Kimia Fakultas Matematika dan Ilmu Pengetahuan Alam Universitas Sam Ratulangi, \\ Jl. Kampus Unsrat, Kleak, Manado 95115 Sulawesi Utara
}

\begin{abstract}
ABSTRAK
Penelitian ini bertujuan untuk menentukan aktivitas antifotoksidasi mengukur nilai SPF dari ekstrak metanol daun Gedi (Abelmoschus manihot L). Daun gedi diekstraksi dengan cara sokletasi. Dalam penelitian ini sampel diekstraksi dengan pelarut metanol, difraksinasi dengan pelarut petroleum eter, etil asetat, butanol dan akuades. Dari hasil fraksinasi tersebut kemudian diuji aktivitas antifotooksidasi dan fotoprotektif. Kandungan fenolik menggunakan asam galat sebagai larutan standart. Uji Aktivitas antifotooksidasi ditentukan dengan menghitung nilai diena terkojugasi yang merupakan pembentukan awal oksidasi pada lipid. Semakin rendah nila diena terkonjugasi, maka semakin baik sebagai antifotooksidasi. Untuk penentuan fotoprotektif, dilakukan dengan mneggunakan spektrofotometer UV-Vis pada panjang gelombang 290-320 nm dengan konsentrasi $100 \mu \mathrm{g} / \mathrm{mL}$. Hasil penelitian ini menunjukkan bahwa fraksi etil asetat memiliki kandungan fenolik, aktivitas antioksidan, antifotooksidasi, dan fotoprotektif yang paling tinggi. Hasil yang diperoleh menunjukkan total fenol paling tinggi pada fraksi eti asetat yaitu $110.204 \mu \mathrm{g} / \mathrm{mL}$, sedangkan untuk aktivitas antioksidan $57.72 \%$. Hasil pada aktivitas antifotooksidasi menunjukkan bahwa fraksi Etil asetat menunjukkan kemampuan yang paling baik dan untuk fotoprotektik memiliki nilai SPF yang tinggi adalah etil asetat yaitu 9.03.
\end{abstract}

Kata kunci: Daun gedi, fenolik, antioksidan, antifotooksidasi, fotoprotektif, SPF

\begin{abstract}
This study aimed to determine the antifotoxidation activity measuring the SPF value of the solvent fraction of the leaves of Gedi (Abelmoschus manihot L). Gedi leaves extracted by socletation. In this study the samples were extracted with methanol solvent, fractionated with petroleum ether, ethyl acetate, butanol and aquades. The results of the fractionation were then tested for antifotooxidation and photoprotective activity. Phenolic content uses gallic acid as a standard solution. The antifotoxidation activity test is determined by calculating the conjugated diene value which is the initial formation of oxidation in the lipid. The lower the conjugated diene tilapia, the better it is antifotoxidation. For photoprotective determination, a UV-Vis spectrophotometer was carried out at a wavelength of $290-320 \mathrm{~nm}$ with a concentration of $100 \mu \mathrm{g} / \mathrm{mL}$. The results of this study indicate that the highest ethyl acetate fraction has the highest phenolic content, antioxidant activity, antifotoxidation and photoprotective. The results obtained showed the highest total phenol in the eti acetate fraction of $110,204 \mu \mathrm{g} / \mathrm{mL}$, while for antioxidant activity $57.72 \%$. The results of the anti photoxidation activity showed that the ethyl acetate fraction showed the best ability and for the photoprotectic the high SPF value was ethyl acetate namely 9.03.
\end{abstract}

Keywords: Gedi leaves, phenolic, antioxidants, antifotooxidation, photoprotective, SPF

\section{PENDAHULUAN}

Tumbuhan gedi (Abelmoschus manihot L) merupakan tanaman yang tumbuh di Sulawesi Utara biasanya digunakan sebagai daun sayuran segar oleh masyarakat sekitar, dan dilaporkan menjadi salah satu sumber antioksidan diantaranya mengandung senyawa fenolik dengan efek terapeutik seperti antibakteri, antikoagulan, dan antioksidan (Taroreh dkk., 2015). Ekstrak daun gedi memiliki kandungan antioksidan yang efektif dalam menghambat radikal bebas sekitar $50 \%$. Ini didasarkan pada penggolongan keefektifan senyawa antioksidan berdasarkan $\mathrm{IC}_{50}$, yakni jika suatu senyawa memiliki nilai $\mathrm{IC}_{50}$
200-1000 ppm tergolong kurang aktif. Namun, masih bersifat antioksidan dan jika suatu senyawa memiliki nilai $\mathrm{IC}_{50}<200 \mathrm{ppm}$ tergolong sangat efektif. Vitamin C digunakan sebagai pembanding memiliki nilai $\mathrm{IC}_{50}$ yang tergolong sangat efektif dalam menghambat radikal bebas.

Black (1999), menyatakan bahwa antioksidan memiliki potensi sebagai fotoprotektor. Oleh karena itu, tanaman fenolik dapat digunakan dalam pencegahan generasi radikal bebas oksigen dan perokisda lipida yang diinduksi oleh cahaya ultraviolet (UV), yaitu peristiwa yang melibatkan keadaan patologis seperti antiaging dan kanker kulit. Paparan sinar matahari dapat menyebabkan berbagai reaksi

\footnotetext{
Korespondensi :

Telpon: +62 858-5775-3700

E-mail : idpwsanger@gmail.com

DOI: https://doi.org/10.35799/cp.12.1.2019.27297
} 
fotokimiawi seperti fotooksidasi. Tabir surya dapat menyerap sedikitnya $85 \%$ sinar matahari pada panjang gelombang 290-320 $\mathrm{nm}$ untuk UVB tetapi dapat meneruskan sinar pada panjang gelombang lebih dari $320 \mathrm{~nm}$ untuk UVA (Suryanto, 2012). Penelitian ini bertujuan untuk menentukan aktivitas antifotoksidasi mengukur nilai SPF dari ekstrak metanol daun gedi. Oleh karena itu, dilakukan penelitian dengan tujuan menganalisis aktivitas antifotooksidasi dan fotoprotektif yang terdapat dalam dain gedi.

\section{BAHAN DAN METODE}

\section{Bahan dan alat}

Bahan yang digunakan antara lain daun gedi, methanol, larutan DPPH, asam linoleat, tween 20, petroleum eter, etil asetat, butanol dan aquades. Alat yang digunakan antara lain alat gelas laboratorium, alat soxhlet, spektrofotometer UV-Vis, rotary evaporator, dan neraca analitik.

\section{Ekstraksi}

Ekstraksi dilakukan dengan cara soxhletasi menggunakan pelarut metanol. Sebanyak $26 \mathrm{~g}$ sampel dibungkus menggunakan kertas saring dan dimasukkan kedalam tabung soxhlet, ditambahkan pelarut metanol sebanyak $250 \mathrm{~mL}$ kemudian di soxhletasi. Filtrat disaring lalu diuapkan untuk menghilangkan pelarutnya dengan menggunakan rotary evaporator, sehingga diperoleh ekstrak kental daun gedi.

\section{Penentuan penangkal radikal DPPH}

Penentuan aktivitas penangkal radikal bebas serbuk daun gedi ditentukan dengan metode Burda \& Oleszec (2001). Sebanyak 0,5 mL masingmasing ekstrak daun gedi $1000 \mu \mathrm{g} / \mathrm{mL}$ ditambahkan dengan 1,5 mL larutan DPPH dan divortex selama 2 menit. Berubahnya warna larutan dari ungu menjadi kuning menunjukkan efisiensi penangkal radikas bebas. Selanjutnya pada 5 menit terakhir menjelang 30 menit waktu inkubasi,absorbansinya diukur pada panjang gelombang $517 \mathrm{~nm}$ dengan menggunakan spektrofotometer UV-Vis. Aktivitas penangkal radikal bebas dihitung sebagai persentase berkurangnya warna DPPH dengan menggunakan persamaan:

$$
\operatorname{APRB}(\%)=\left(1-\frac{\text { absorbansi sampel }}{\text { absorbansi kontrol }}\right) \times 100 \%
$$

\section{Penentuan potensi antifotooksidasi terhadap asam linoleat}

Dibuat stok emulsi dari 1,5 $\mathrm{g}$ asam linoleat ditambahkan $6 \mathrm{~mL}$ aquades, distierer selama 5 menit, lalu ditambahkan 2,5 gr tween 20 kemudian distirer kembali selama 10 menit. Diambil $1 \mathrm{~g}$ stok tersebut, dan ditambahkan $5 \mathrm{~mL}$ aquades distirer selama 2 menit, selanjutnya ditambah $5 \mathrm{~mL}$ aquades sebanyak 4 kali penambahan sehingga total stirrer sebanyak 10 menit. Pengaruh masingmasing ekstrak terhadap oksidasi oksigen singlet diuji dalam asam linoleat yang mengandung 5 $\mu \mathrm{g} / \mathrm{mL}$ eritrosin dalam emulsi sebagai sensitiser.

Efek ekstrak terhadap fotooksidasi asam linoleat menggunakan konsentrasi $500 \mu \mathrm{g} / \mathrm{mL}$. Sampel dari campuran tersebut diambil sebanyak $5 \mathrm{~mL}$ dan dimasukkan ke dalam botol serum berukuran $10 \mathrm{~mL}$ yang dilengkapi dengan penutup karet dan aluminium foil. Analisis hidroperroksida diena terkonjugasi dilakukan selama 5 jam penyinaran. Pengukuran nilai hidroperoksida diena terkonjugasi dimulai dengan memipet sampel emulsi $30 \mu \mathrm{g} / \mathrm{mL}$. Sampel tersebut dimasukkan ke dalam tabung reaksi yang telah berisi $3 \mathrm{~mL}$ metanol absolute. Absorbansi diukur pada panjang gelombang $234 \mathrm{~nm}$. Setelah diketahui absorbansi, dengan rumus LambertBeer $(A=\varepsilon b c)$ maka dapat dicari konsentrasi hidrokperoksida diena terkonjugassi karena diketahui: $\varepsilon=26000 \mathrm{M}-1 \mathrm{~cm}-1$ untuk linoleat hidro peroksida, $\mathrm{b}=1 \mathrm{~cm}$

\section{Penentuan nilai SPF secara in vitro}

Penentuan efektifitas fotooksidasi daun dilakukan dengan penentuan nilai SPF secara in vitro untuk sampel petroleum eter, etil asetat, butanol dan aquades dengan konsentrasi 1000 $\mu \mathrm{g} / \mathrm{mL}$ menggunakan spektrofotometer UV/Vis pada panjang gelombang 290-320 nm. Berikut adalah perhitungan nilai SPF menurut Mansur dkk. (1986):

$$
\mathrm{SPF}=\mathrm{CF} \times \sum_{290}^{320} \operatorname{EE}(\lambda) x \mathrm{I}(\lambda) x \text { absorbansi }(\lambda)
$$

Keterangan CF: faktor koreksi (10), EE: Efisiensi Eritemal, I: spectrum simulasi sinar surya dan abs (I) absorbansi produk tabir surya.

\section{HASIL DAN PEMBAHASAN}

\section{Ekstraksi}

Menurut Harborne (1987) pelarut metanol diduga mempunyai sifat yang dapat melarutkan semua jenis komponen yang berupa senyawa polar, non polar dan semi polar. Proses sokletasi 
akan menghasilkan filtrat dan residu. Filtrat yang didapat kemudian dilanjutkan pada tahap fraksinasi. Pada roses ekstraksi sokletasi serbuk daun gedi (Abelmoscus manihot $L$ ) menghasilkan ekstrak sebanyak 1.093g dengan ekstrak berwarna cokelat dan diperoleh nilai rendemennya sebesar $6.83 \%$ dan juga senyawa fenoliknya $43.78 \mu \mathrm{g} / \mathrm{mL}$.

\section{Fraksinasi}

Ekstraksi cair-cair merupakan proses pemisahan terlarut dari cairan pembawanya (diluen) dengan menggunakan pelarut cair. Dalam prosedur telah dijelaskan tentang cara dan prinsip kerja dari partisi cair-cair yaitu dengan penggunaan lebih pelarut polar dan nonpolar, karena prinsip ekstraksi adalah senyawa polar cenderung lebih larut dalam pelarut polar dan sebaliknya. Berdasarkan Tabel 1 dapat dilihat bahwa keseluruhan berat rendemen memiliki angka di bawah 1 (satu). Hal tersebut dipengaruhi oleh jumlah rendemen awal dari ekstrak metanol.

Tabel 1. Rendemen dari fraksi fraksi daun gedi

\begin{tabular}{ccc}
\hline Fraksi & Berat akhir $(\mathrm{g})$ & Rendemen $(\%)$ \\
\hline PE & 0,14 & 13,81 \\
EA & 0,21 & 21,15 \\
B & 0,23 & 23,38 \\
AK & 0,73 & 72,64 \\
\hline
\end{tabular}

Keterangan: PE (fraksi petroleum eter), EA (fraksi etil asetat), B (butanol), AK (akuades)

Taroreh dkk. (2015) menyatakan bahwa metanol dapat mengekstraksi senyawa-senyawa yang bersifat polar seperti senyawa fenolik, protein dan karbohidrat. Sedangkan heksana dan aseton dapat melarutkan senyawa-senyawa yang kurang polar seperti lemak, fosfolipid, klorofil serta senyawa fenolik yang kurang polar. Hal ini menunjukkan bahwa komponen senyawa bersifat polar pada daun gedi persentasenya lebih besar dibandingkan dengan komponen senyawa yang bersifat non polar. Oleh karena itu digunakan ekstrak metanol yang kemudian lanjutkan kefraksinasi dengan cara ektraksi cair-cair.

\section{Penentuan aktivitas penangkal radikal bebas}

Senyawa yang bereaksi sebagai penangkap radikal akan mereduksi DPPH membentuk DPPH$\mathrm{H}$ yang tereduksi. Reaksi ini diamati dengan adanya perubahan warna DPPH dari ungu menjadi kuning ketika elektron ganjil dari radikal DPPH telah berpasangan dengan hidrogen dari senyawa penangkap radikal bebas (Molyneux dalam Malangngi 2004). Metode DPPH merupakan metode yang sederhana, mudah untuk penapisan aktivitas penangkapan radikal beberapa senyawa, efektif dan praktis (Molyneux, 2003).

Senyawa yang berperan dalam menangkal radikal diduga adalah tanin. Hal ini dikarenakan senyawa tanin dapat berikatan dengan protein. Tanin merupakan senyawa kimia yang tergolong dalam senyawa polifenol (Deaville dkk., 2010). Perbedaan kemampuan antioksidatif senyawa antioksidan ini terhadap radikal bebas DPPH disebabkan karena perbedaan kemampuan mentransfer atom hidrogen (Nakiboglu dkk., 2007). Metode DPPH merupakan senyawa radikal nitrogen. DPPH akan mengambil atom hidrogen yang terdapat dalam suatu senyawa, misalnya senyawa fenol. Pengujian aktivitas penangkal radikal bebas ini dilakukan dengan mereaksikan larutan ekstrak masing-masing fraksi dengan larutan DPPH dan selanjutnya dibaca absorbansinya pada panjang gelombang $517 \mathrm{~nm}$. Metode penangkalan radikal ini melalui mekanisme pengambilan atom hidrogen dari senyawa antioksidan oleh radikal bebas sehingga radikal bebas ini menangkap satu elektron dari senyawa antioksidan (Pokorny dkk., 2001) Hasil uji aktivitas antioksidan dengan metode DPPH dapat dilihat pada Gambar 1.

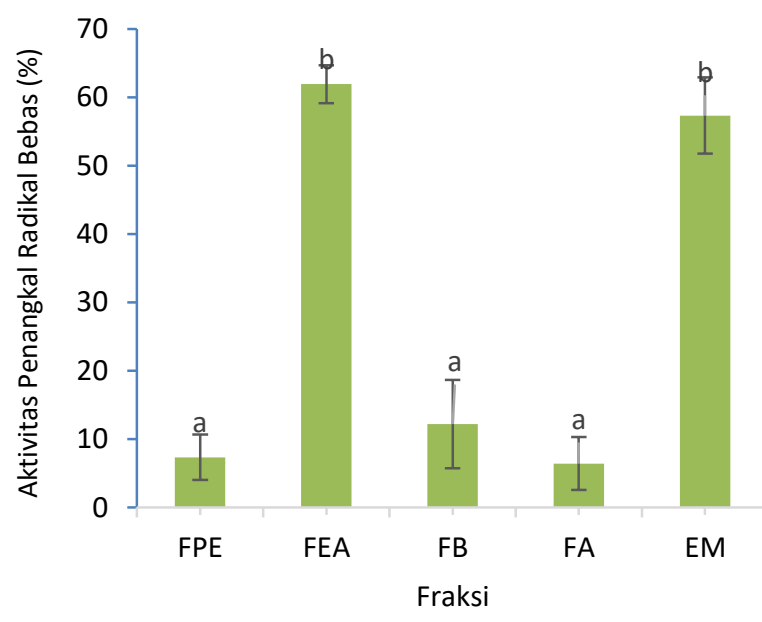

Gambar 1. Penangkal radikal bebas dari ekstrak metanol dan fraksi pelarut daun gedi. Keterangan: fraksi petroleum eter (FPE), fraksi etil asetat (FEA), fraksi butanol (FB), fraksi air (FA) dan ekstrak metanol (EM).

Berdasarkan Gambar 2 dapat diketahui bahwa hasil analisis penangkal radikal bebas terhadap fraksi etil asetat menunjukkan persentase penangkal radikal bebas pada daun gedi memiliki 
aktivitas antioksidan yang paling tinggi etil asetat sebesar $(57,72 \%)$ apabila dibandingkan dengan ekstrak metanol (61.91\%), fraksi butanol (7,33\%), fraksi petroleum eter $(12,17 \%)$, dan fraksi air $(6,414 \%)$. Hal ini membuktikan bahwa hasil ini hampir berbanding lurus dengan kandungan fenolik dari hasil masing-masing fraksi tersebut.

\section{Potensi fotooksidasi terhadap asam linoleat}

Dalam Gambar 2 asam linoleat yang tidak diberi cahaya tidak mengalami perubahan, begitupun sebaliknya. Maka dapat dikatakan bahwa semakin rendah dinilai diena terkonjugasi maka semakin baik suatu sampel sebagai antifotooksidasi. Cahaya berpengaruh pada proses pembentukan oksigen singlet, dengan demikian oksigen singlet yang terbentuk pada keadaan tanpa cahaya (K2) sangatlah kecil sehingga menghasilkan diena terkionjugasi yang kecil pula. Gambar 3 menunjukkan kandungan diena terkonjugasi dalam emulsi dari ekstrak daun gedi dengan konsentrasi $500 \mu \mathrm{g} / \mathrm{mL}$.

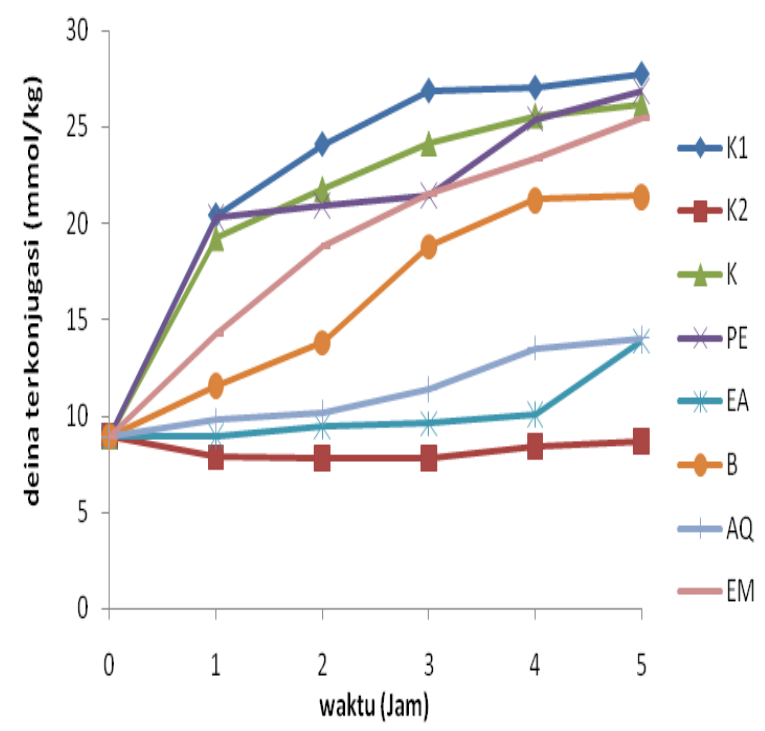

Gambar 2. Kandungan diena terkonjugasi dari fraksi pelarut petroleum eter (FPE), fraksi etil asetat (FEA), fraksi butanol (FB), fraksi air (FA), ekstrak metanol (EM), kontrol cahaya (K1), kontrol tanpa cahaya (K2), kontrol emulsi (K).

Pengaruh 500 ppm ekstrak daun gedi terhadap diena terkonjugasi asam linoleat yang diberi cahaya dapat dilihat dalam gambar 3, fraksi EA mempunyai pengaruh yang paling kuat untuk penstabil oksigen singlet dibandingkan dengan fraksi lainnya. Pada konsentrasi tinggi eritrosin juga mempengaruhi fotooksidasi asam linoleat hal ini dibuktikan dalam penelitian Suryanto dkk. (2004) dimana eritrosin dibandingkan dengan riboflavin pada konstrasi yang sama namun dudapatkan hasil bahwa eritrosin lebih efektik.

Dari data tersebut diperoleh bahwa semua fraksi memiliki kemampuan untuk menghambat oksidasi oksigen singlet dengan kapasitas masingmasing. Hal ini menunjukkan bahwa fraksi etil asetat mampu melindungi lipid yang terdapat pada sistem emulsi. Diikuti dengan fraksi air, fraksi butanol, eksktrak methanol, dan fraksi petroleum eter. Pada pengujian ini, fraksi air juga menunjukkan hasil yang tidak jauh berbeda dengan fraksi etil asetat pada sampel uji.

Fotosensitizer seperti eritrosin dapat menyerap cahaya dan mentransformasikan menjadei keadaan tereksitasi selanjutnya berubah menjadi sensitizer pada kaadaan triplet yang kurang stabil. Sensitizer dapat memindahkan energinya pada oksigen pada keadaan triplet yang lebih stabil karena tinggkat energy sensitizer sangat tinggi sehingga dapat mengubah oksigen triplet menjadi oksigen singlet yang menyerang ikatan rangkap dalam asam linoleat. Suryanto dkk. (2004).

\section{Penentuan SPF secara in vitro}

Analisis secara in vitro, dilakukan dengan menggunakan metode spektrofotometri UV-Vis dengan cara menghitung nilai absorbansi sampel yang dibaca pada panjang gelombang 290-400 nm kemudian setiap interval $5 \mathrm{~nm}$. Penentuan efek fotoproteksi dilakukan dengan penentuan nilai SPF secara spektrofotometer UV-Vis menggunakan panjang gelombang 290 sampai 320 $\mathrm{nm}$ (sesuai panjang gelombang UV-B). Nilai SPF dari kelima fraksi pelarut dan ekstrak metanol daun gedi pada konsentrasi $100 \mu \mathrm{g} / \mathrm{mL}$ dapat dilihat pada Gambar 3.

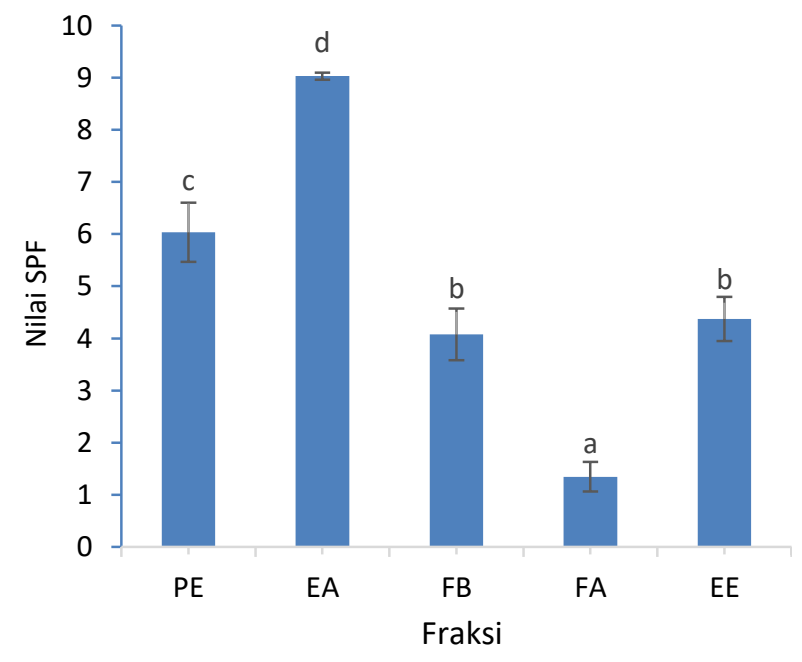

Gambar 4. Perbandingan nilai SPF dari ekstrak metanol dan fraksi pelarut dari daun gedi. 
Dari Gambar 3, dapat diketahui bahwa fraksi etil asetat memiliki nilai SPF yang paling tinggi yaitu 9.03 diikuti dengan petroleum eter sebesar 6.04, ekstrak metanol 4.37, fraksi butanol, fraksi air merupakan nilai terendah dari semua ekstrak. Data ini mengindikasikan bahwa fraksi etil asetat memiliki kemampuan sebagai fotoproteksi terhadap sinar matahari khususnya UV-B. Dalam penelitian yang dilakukan oleh Wulandari (2017) Hasil uji pada tikus putih setelah dioleskan krim ekstrak daun soyogik, tikus tidak memiliki eritema karena mempunyai Proteksi ultra sebagai perlindungan tabir surya. tikus yang terjadi iritasi sejak bulu punggung tikus dicukur, tapi setelah dilakukan penyinaran dengan krim ekstrak dan kontrol positif, kulit punggung tikus yang iritasi bisa sembuh. Proses penyembuhan iritasi pada punggung tikus karena adanya kandungan senyawa flavonoid pada ekstrak daun soyogik.

\section{KESIMPULAN}

Berdasarkan hasil yang didapatkan dari penelitian ini, maka dapat dambil kesimpulan bahwa fraksi etil asetat dari ekstrak metanol daun gedi memiliki aktivitas antifotooksidasi lebih efektif dibandingkan dengan fraksi butanol, fraksi petroleum eter, dan fraksi air. Hal ini dapat dilihat dari kemampuan fraksi dalam melindungi lipid pada sistem emulsi yang induksi dengan cahaya. Hasil penelitian ini juga menunjukkan bahwa fraksi etil asetat mempunyai aktivitas fotoprotektif paling tinggi daripada ekstrak metanol, fraksi petroleum eter, fraksi butanol dan fraksi air.

\section{DAFTAR PUSTAKA}

Black, H.S., 1990. Antioxidant and caretenoids as potential photo-protectans. Sunscreen development evaluation and regularitory prospects. 10: Marcel Dekker Inc., New York.

Burda, S.W., \& Oleszek. 2001. Antioxidant and antiradical activities of flavonoids. Jurnal of
Agriculture and Food Chemistry. 49 (6), 2774-2779.

Harborne, J. B. 1987. Metode Fitokimia, Penuntun cara modern menganalisis tumbuhan. Terjemahan K. Padmawinata dan I Soediro. ITB, Bandung.

Wungkana, I., Suryanto, E. \& Momuat, L. 2013. Aktivitas antioksidan dan tabir surya fraksi fenolik dari limbah tongkol jagung (Zea mays L.). PHARMACON. 4 (2), 149-155.

Jeong, S.M., Kim, S.Y., Kim, D.R., Jo, S.C., Nam, K.C., Han, D.U. \& Lee, S.C. 2004. Effect of heat treatment on the antioxidant activity of extracts from citrus peels. Journal of Agricultural and Food Chemistry 52(11), 3389-3393.

Katja, D.G. \& Suryanto, E. 2009. Efek penstabil oksigen singlet ekstrak pewarna dari daun yayam terhadap fotooksidasi asam linoleat, protein dan vitamin C. Chemistry Progress. 2 (2), 79-86.

Malangngi, P.L., Sangi, S.M. \& Paendong, J.E. Jessy. 2012. Penentuan kandungan tanin dan uji aktivitas antioksidan ekstrak biji buah alpukat (Persea americana Mill. Jurnal MIPA UNSRAT. 1(1), 5-10.

Suryanto, E. 2012. Fitokimia antioksidan. Putra Media Nusantara, Surabaya.

Suryanto, E., Raharjo, S., Sastrihamidjojo \& Tranggono. 2004. Aktivitas antiradikal ekstrak buah andalamin (Zanthoxylum acanthopodium DC). Indonesian Food and Nutrion Progress. 11(1), 16-20.

Taroreh, M., Raharjo, S., Hastuti, P. \& Murdiati, A. 2014. Antioxidant activities of various solvent extracts of gedi's (Abelmoschus manihot) leaves. Report of International Conference on food for a quality life. Indonesia: The Indonesian Association of Food Technologist. 9 (2016), 271-278.

Wulandari, S. Sartika., Runtuwene, R.J. Max., Wewengkan, S. Defny. 2017. Aktivitas perlindungan tabir surya secara in vitro dan in vivo dari krim ekstrak etanol daun Soyogik (Saurauia bracteosa DC). Jurnal Pharmacon. 3(6), 147-156. 